\title{
Archival Research of the History of the Francisco Flores Ranch
}

Adriana Munoz Ziga

City of San Antonio Office of Historic Preservation

Follow this and additional works at: https://scholarworks.sfasu.edu/ita

Part of the American Material Culture Commons, Archaeological Anthropology Commons, Environmental Studies Commons, Other American Studies Commons, Other Arts and Humanities Commons, Other History of Art, Architecture, and Archaeology Commons, and the United States History Commons

Tell us how this article helped you.

This Article is brought to you for free and open access by the Center for Regional Heritage Research at SFA ScholarWorks. It has been accepted for inclusion in Index of Texas Archaeology: Open Access Gray Literature from the Lone Star State by an authorized editor of SFA ScholarWorks. For more information, please contact cdsscholarworks@sfasu.edu. 


\section{Archival Research of the History of the Francisco Flores Ranch}

\section{Licensing Statement}

Reproduction, posting, transmission, or other distribution or use of the Journal volume, individual article or any portion of the material therein, in any medium, is permitted strictly for personal, non-commercial purposes via a personal-use exemption under a Creative Commons license granted by JTAH.org, Inc. This license exemption requires, as a condition of its granted permission, proper credit be attributed to JTAH.org as copyright holder (e.g., Journal of Texas Archeology and History.org @ 2014). No part of this publication may be reproduced, posted, transmitted, or otherwise utilized or distributed in any form by any means or method for commercial purposes without the express written consent of the Publisher.

Inquiries should be addressed to JTAH Publisher, Suite 307, Box 361, 5114 Balcones Woods Drive, Austin, Texas, 78759.

The Journal of Texas Archeology and History.org is an organization dedicated to furthering research, education and public outreach in the fields of archeology and history concerning Texas and its bordering states of Louisiana, Arkansas, Oklahoma, New Mexico and Northern Mexico; a region we call the "Texas Borderlands." The J.T.A.H. is collaborating with the Index of Texas Archaeology and S.F.A.S.U. to distribute their publication library to the general public via free and open-access channels. Visit www.JTAH.org to submit an article. 


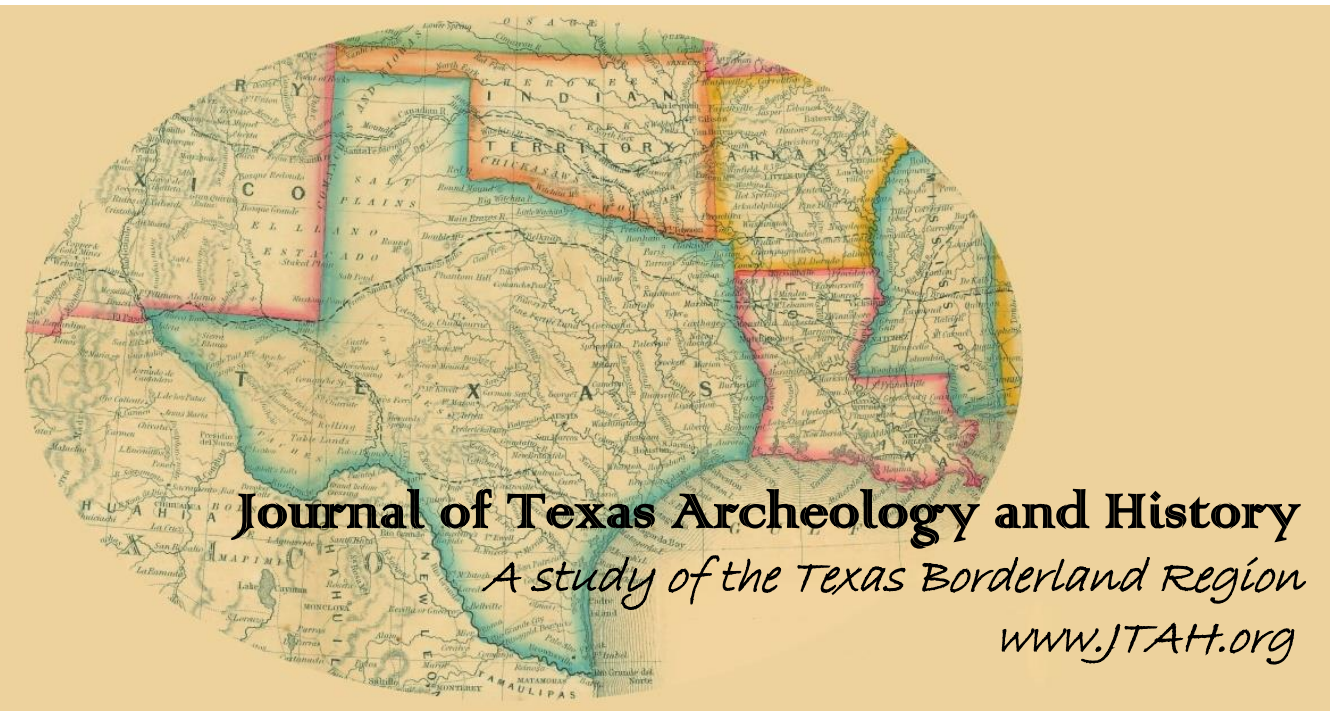

\section{Article Title: ARCHIVAL RESEARCH OF THE HISTORY OF THE FRANCISCO FLORES RANCH \\ Author(s): $\quad$ Adriana Munoz Ziga}

Original Source: J.T.A.H. Volume 1 (2014), Article 6, pp. 127-150; online 11 December 2014

Recommended Citation: Ziga, Adriana Munoz; "Archival Research of the History of the Francisco Flores Ranch", (2014), Journal of Texas Archeology and History Volume 1 (2014), pp. 127-150.

Copyright (C 2014 by Journal of Texas Archeology and History.org, Inc. All rights reserved. Online/Digital publication: ISSN 2334-1874

The online, digital and print versions of the publication "Journal of Texas Archeology and History" are published by Journal of Texas Archeology and History.org, Inc., a Texas nonprofit IRC Section 501(c)(3) corporation.

Reproduction, posting, transmission, or other distribution or use of the Journal volume, individual article or any portion of the material therein, in any medium, is permitted strictly for personal, non-commercial purposes via a personal-use exemption under a Creative Commons license granted by JTAH.org, Inc. This license exemption requires, as a condition of its granted permission, proper credit be attributed to JTAH.org as copyright holder (e.g., Journal of Texas Archeology and History.org (C) 2014). No part of this publication may be reproduced, posted, transmitted, or otherwise utilized or distributed in any form by any means or method for commercial purposes without the express written consent of the Publisher. Inquiries should be addressed to JTAH Publisher, Suite 307, Box 361, 5114 Balcones Woods Drive, Austin, Texas, 78759.

The Journal of Texas Archeology and History.org is an organization dedicated to furthering research, education and public outreach in the fields of archeology and history concerning Texas and its bordering states of Louisiana, Arkansas, Oklahoma, New Mexico and Northern Mexico; a region we call the "Texas Borderlands." The J.T.A.H. is collaborating with the Index of Texas Archaeology and S.F.A.S.U. to distribute their publication library to the general public via free and open-access channels. Visit www.JTAH.org to submit an article. 


\title{
ARCHIVAL RESEARCH OF THE HISTORY OF THE FRANCISCO FLORES RANCH
}

\author{
Adriana Muñoz Ziga
}

\begin{abstract}
The Francisco Flores Ranch, located northwest of Floresville, Texas, encompassed five sitios of land and one labor on the west bank of the San Antonio River at the paraje known as Chayopines. The Flores Ranch is one of the last surviving privately owned colonial ranches that have been identified in the San Antonio River valley containing standing structures possibly dating to the original date of occupation. I outline previous research on the property and offer new interpretations on the farm and ranch complex.
\end{abstract}

\section{INTRODUCTION}

Francisco Antonio Flores de Abrego was a Canary Island immigrant who settled the area around the town of Lodi, which became present day Floresville (Hazlewood 2010). The Francisco Flores Ranch, located northwest of Floresville, Texas, encompassed five sitios of land and one labor on the west bank of the San Antonio River at the paraje known as Chayopines. In order to understand the property, one must comprehend the history of the area and early settlement along the San Antonio River.

Much of the area along the San Antonio River belonged to the San Antonio missions (Figure 1). The main goal of the missions was to become self-sufficient, which meant that they each had to grow enough food and raise enough cattle to support its inhabitants (Cargill et. al. 1998:7). Missions had additional land outside their complexes that was used for agriculture and grazing. The boundaries of these ranch areas were never clearly defined as "none of the [San Antonio] missions were established with their later ranch lands included in the original land grant," and ownership shifted between missions at diff rent periods in time (Cargill et al. 1998:7). Once private ranchers began settling in the area, confusion between the mission land and private ranches' boundaries was common, since in many cases no title existed and descriptions were based on individual accounts.

Evidence suggests that multiple Chayopines ranchos on either side of the river existed since the area was first settled. Archival documents show that at least four ranches using the name Chayopines were present in the area between 1760-1810, including Francisco Flores' ranch; this has added to the confusion concerning the property's history over the years. I attempt to reconcile the differences through archival research of primary and secondary sources, including original Spanish documents.

\footnotetext{
JOURNAL OF TEXAS ARCHEOLOGY AND HISTORY

VOLUME 1:127-150

THE ONLINE PUBLICATION JOURNAL OF TEXAS ARCHEOLOGY AND HiSTORY (ISSN 2334-1874)

IS PUBLISHED BY JOURNAL OF TEXAS ARCHEOLOGY AND HISTORY.ORG. COPYRIGHT (c) 2014 JOURNAL OF TEXAS ARCHEOLOGY AND HistORY.ORG. AlL RIGHTS RESERVED.
} 


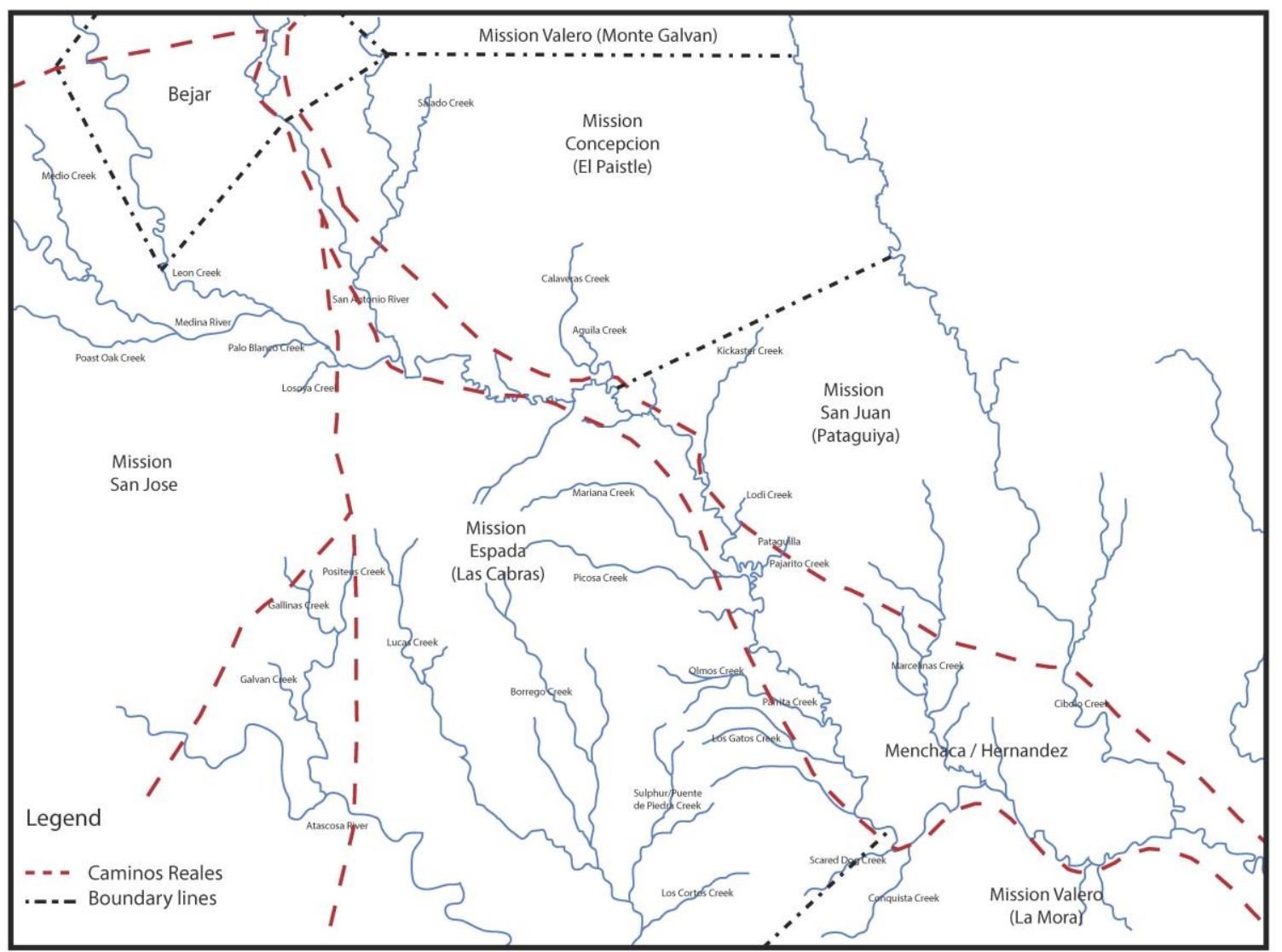

Figure 1. Ranch Lands of the San Antonio missions, showing mission fields in 1770-1771.

\section{RANCHO DE SAN YLDELFONSO DE LOS CHAYOPINES}

The first recorded private settler of the area around the Flores Ranch appears to have been Martin de la Pena with his Rancho de San Yldelfonso de los Chayopines in 1768 (Oca 1778). As mentioned previously, mission ranch lands were not included in their original land grants, and this created confusion concerning the boundaries between the missions and their private neighbors. This confusion led to the litigation of 1768-1772 between the lands of Mission Concepcion, Espada, and Valero and private landowners including Vicente Alvarez Travieso, the heirs of Martin Lorenzo de Armas, Domingo Delgado, Jacinto Delgado, and Manuel Delgado (Pena 1770). During the litigation, the ranch lands of the three missions were re-surveyed using actual field measurements of the areas the missions were actively using and those that were not being actively used (Ivey 1991:35). At that time it was determined that Martin de la Pena's ranch was occupying land belonging to Mission Espada, which led to litigation between the two parties (Pena 1770). The notice issued by Don Simon de Arocha in June of 1770 regarding this issue reads as follows:

respecto a que dicha informacion resulta a si mismo que Don Martin de la Pena en las tierras que tiene pobladas como de tres anos esta parte esta entrado como un cuarto de legua en las que posee dicha mision de la Espada por la parte del norte en el Paso que llaman de los Chayopines (Pena 1770). 
In respect to said information, resulting indeed that Don Martin de la Pena in the lands he has inhabited for about three years, has encroached about a quarter of a league in the ones owned by the said Mission Espada, on the north part at the crossing known as Chayopines (all translations are by the author).

Martin de la Pena responded to this notice:

desde el ano de mil cetecientos sesenta y ocho es verdad aver poblado el paraje de los chayopines con mi hijo y tres mozos, que me puse con buena fee, siendo con el permiso expreso de el Senor Governador interino Don Hugo Oconor y con la licencia del Senor Capitan Don Luis Antonio Menchaca, aviendome informado primero de que dicho sitio no estaba comprehendido en los agostaderos de la Mision de la Espada...pues estando el terreno que ocupo entre el paso de los Chayopines y el que llaman de las Mujeres (Pena 1770).

From the year of 1768 , it is true I have inhabited the paraje de los Chayopines with my son and three servants, that I settled in good faith, being with the expressed permission of the Interim Governor Don Hugo Oconor and with license of Captain Don Luis Antonio Menchaca, informing myself first that said land was not included in the pastures of Mission Espada...thus being the land I occupy between the Chayopines crossing and the one called las Mujeres.

It is known that Rancho las Cabras on the west bank of the river belonged to Mission Espada (Cargill et. al. 1998:7). If Pena encroached $1 / 4$ of a league (0.66 miles) over the north boundary of Mission Espada lands, it is likely that his ranch was on the west bank of the river north of Las Cabras. At the end of the litigation Espada's northern boundary was moved south at Janisos/Los Alamos/Pena creek, and the area between Pena's southern boundary at Chayopines crossing and the new northern boundary for Las Cabras (Figure 2) was made available to private ranchers for lease (Ivey 1991:38). Pena never received clear title during the 1770 litigation, which opened him up to a lawsuit between Juan Joseph Montes de Oca and his Rancho de la Candelaria and Ygnacio de la Pena, Jose Martin's son and the Rancho de los Chayopines in 1778 (Oca 1778).

To clarify further we can look at the 1778 claim over this land. According to Montes de Oca his lands went:

de la junta del Rio de Medina con este de San Antonio hasta donde entra el arroyo de los alamos con el propio rio lindando por el sur con tierras pertenesientes al rancho de la Mission de la Espada por el Poniente con el arroyo del Borrego y por Norte y oriente con tierras de la Mission de San Juan que serán quatro sitios de ganado mayor de largo y de ancho quando mas tres cuartos de legua de tierra (Oca 1778). 


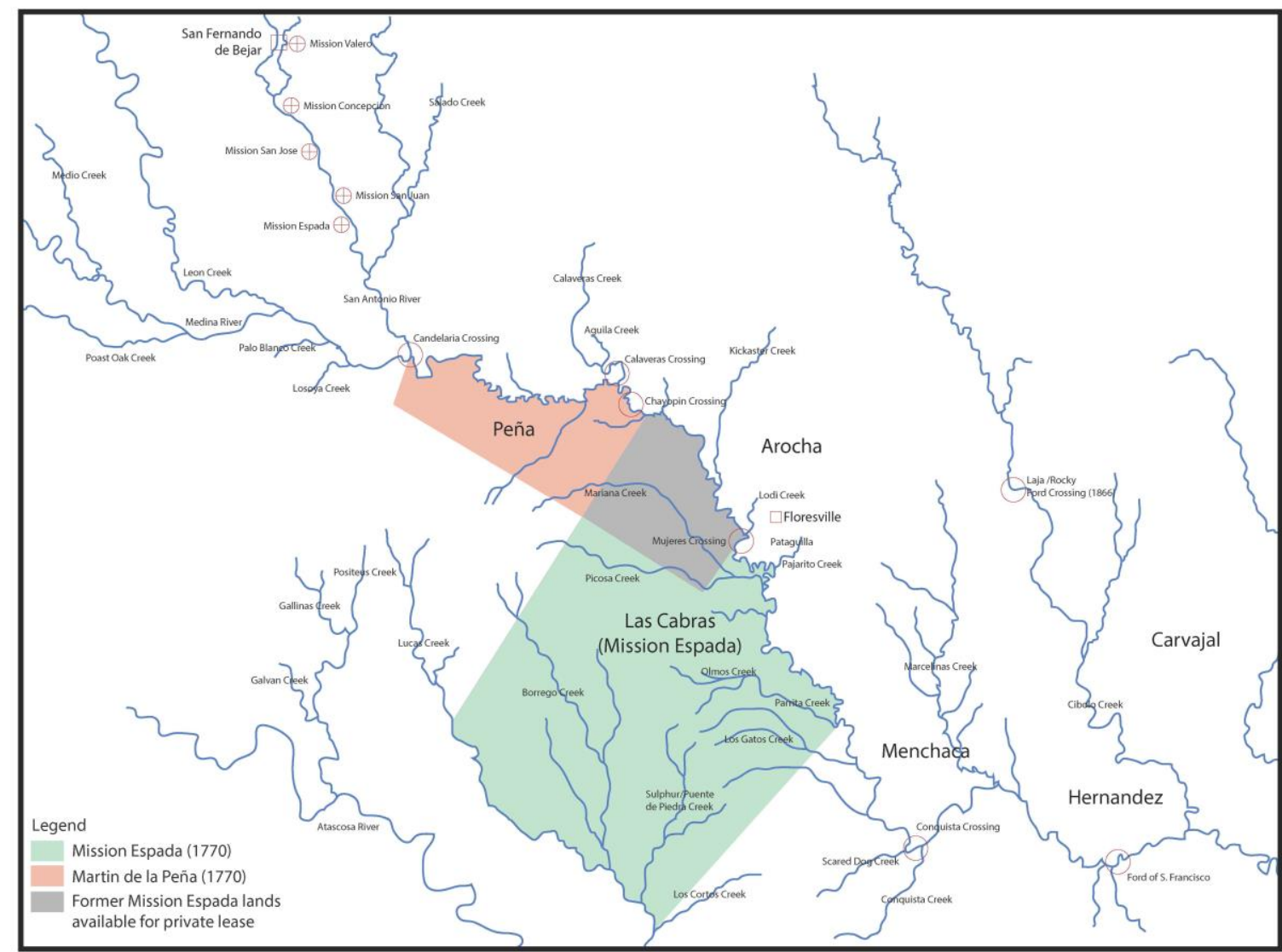

Figure 2. Map showing lands of Mission Espada and Martin de la Pena in 1770. Figures 2-6 are based on information available to the author at this time. Further research is necessary to confirm boundaries.

From the mouth of the Medina River at the San Antonio, to the mouth of Elm Creek with the said river, adjoining to the south, lands belonging to the ranch of Mission Espada, to the west with Borrego creek, and to the north and east with lands of Mission San Juan. That might be four sitios of ganado mayor in length and at least $3 / 4$ of a league in width.

His account appears problematic since the area Montes de Oca describes is much larger than the four sitios he claims it to be. However, all of the markers noted on his description are located west of the San Antonio River. On January 1778 Baron de Ripperda wrote after visiting the de la Pena family to settle Montes de Oca's claim:

Halle poblado el rancho llamado los Chayopines por Don Martin de la Pena padre de Don Josef Antonio Yldelfonso de la Pena cura parroco que era de esta poblacion donde se puso desde el mes de marzo de mil setezientos sesenta y ocho hallándose Juan Josef Montes en el rincón de la Candelaria como expresa con una laborcita aunque no de continua asistencia y retirándose de dicho parage continuaron los hijos del sitado Don Martin de la Pena teniendo poblado aun quando todos los ranchos se despoblaron por las hostilidades de los indios nortenos mediante su mas favorable situación en cuya atención y el perjuicio que a dichos pobladores resultava devolverse a establecer el sitado Juan Josef Montes en el referido parage no permitiéndoselo condecendi a que se estableciera tres o mas leguas rio 
arriba junto al paso de Josef Miguel con motivo de tener a su cuidado unas reses dadas al ssma. donde hizo corral y jacal pero sin mantenerlo poblado mas que para las juntas de su ganado manifestándose no procede con la devida realidad en lo que expone respecto ser parte de las tierra que zita comprehendidas en las medidas que de superior orden se hicieron y posee la misión de la espada como por que componen mucho mas que duplicado terreno de los quatro sitios de ganado mayor de largo y tres quartos de legua de ancho que supone (Oca 1778).

I found the ranch named los Chayopines inhabited by Don Martin de la Pena, father of Don Josef Antonio Yldelfonso de la Pena, who was parochial priest of this town, where he settled since the month of March of 1768, being Juan Josef Montes at the Rincon de la Candelaria as he expresses, with a small labor although not of continuous assistance, and [after] removing himself from the said paraje, the sons of the said Don Martin de la Pena continued inhabiting even when all the ranches became uninhabited due to the hostilities of the northern Indians. Through his most favorable situation in which attention and the perjury that re-establishing caused those inhabitants not permitting the said Juan Josef Montes at the said paraje, I conceded him to establish three or four leagues upriver next to the Josef Miguel crossing so that he could have under his care some cattle given to His Excellency, where he built a corral and jacal but inhabiting it only while gathering his cattle. Manifesting to not proceed with the necessary reality in what he presents in respect to being part of the lands he cites within the measures that by superior order were made and belong to the Mission Espada, as they compose much more than double land from the four sitios de ganado mayor in length and 3/4 of a league in width that he supposes.

Baron de Ripperda noted the issue between Montes de Oca's claim and the actual size of the described property. On a subsequent letter Martin de la Pena described the boundaries of his ranch as follows:

desde el Paso que llaman de Jose Miguel en el Rio de este Presidio por de este lado, hasta el de las Mugeres con su fondo correspondiente hasta el complete de sinco sitios de ganados maiores (Oca 1778).

From the crossing called Jose Miguel at the River of this presidio, through on this side, to the Mujeres with its corresponding end at the completion of five sitios of ganado mayor.

The boundaries of the property were expanded considerably from the description given by Martin de la Pena in 1770 to the one from 1778 (Figure 3). It is important to note that during this time Ignacio Calvillo was petitioning to rent land from Chayopines to Mujeres crossing that he had been using since 1775 as his Rancho de las Mujeres (Ivey 1991:41). Calvillo had settled the area between the northern boundary of Las Cabras (as determined during the 1770 litigation between the private ranchers and the missions) and the southern boundary of Pena's ranch just south of Chayopines Crossing. Although this area appears to have stayed in control of Mission Espada, private citizens were allowed to lease this land, which allowed Calvillo to rent and establish his ranch as mentioned previously. No full legal title appears to have been issued to Pena or Montes de Oca during the 1778 
lawsuit but the Pena family occupied the land until at least 1791 (Ivey 1991:41). Montes de Oca did not receive his request to dispossess Pena of his land, but does seem to have been granted a ranch on the north side of the San Antonio River, between La Bahia Road and Mission San Juan lands to the north, and Salado Creek to the west (Ivey 1991:41). At any rate, evidence seems to be clear in locating the Pena ranch on the west bank of the river north of Las Cabras.

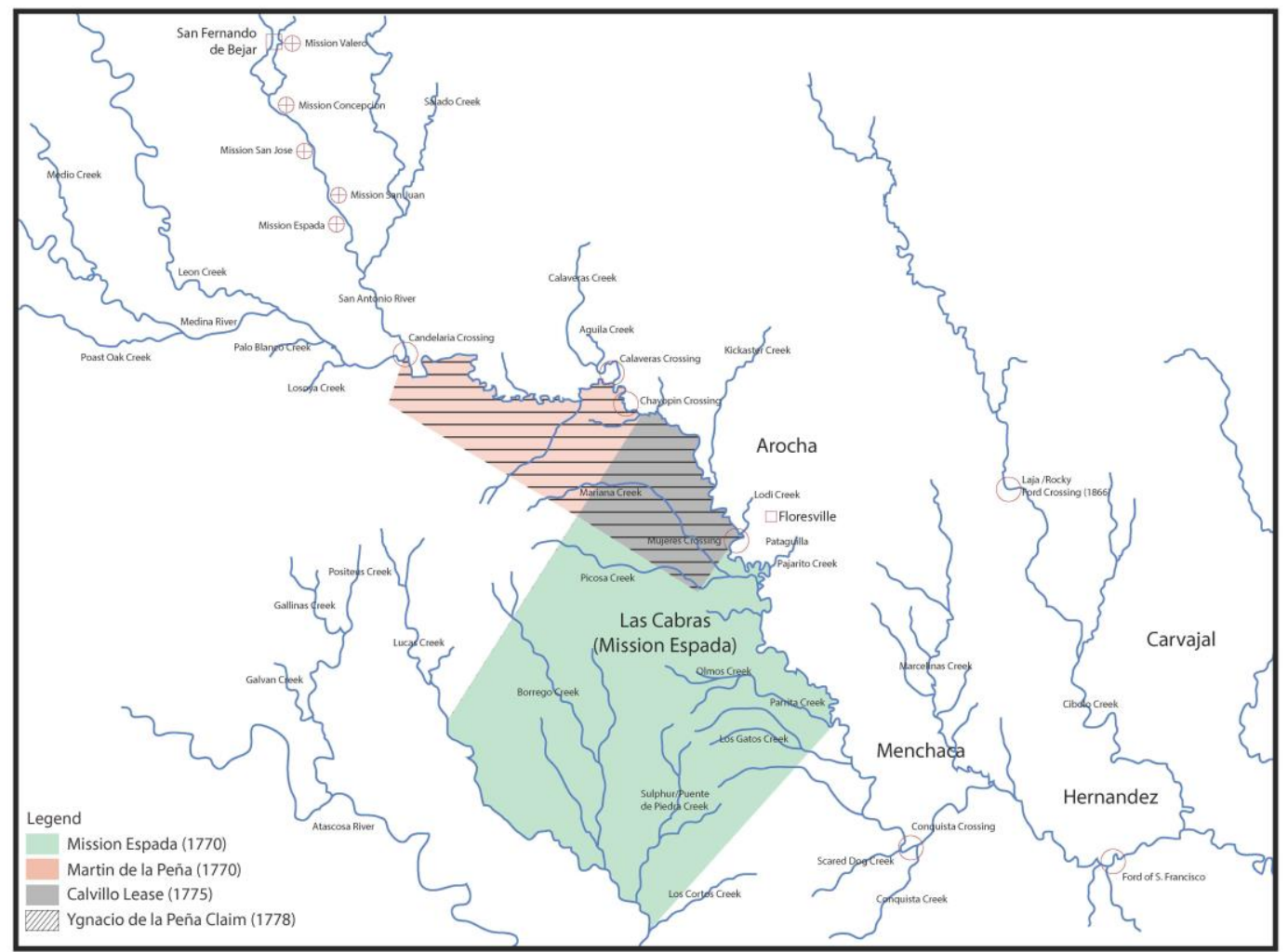

Figure 3. Map showing lands of Ygnacio de la Pena in 1778.

\section{FRANCISCO FLORES ACQUISITION OF CHAYOPINES RANCH}

In 1773, Ignacio Calvillo requested title of the Rancho de las Mujeres between Rancho de las Cabras and Chayopines Crossing. It is likely he received it since he was recognized as a landowner in the area in future documents. At some point after securing a lease to use the land, he lost part of the property due to failing to pay rent in about 1780, and it appears the two sitios he lost were immediately re-granted to Francisco Flores (Ivey 1991:42). According to the proceedings of a case between Mariana Curbelo versus Vizente Flores in 1783, Vizente, his father Francisco, and his cousins Juan Jose and Joaquin were operating a ranch at Chayopines (Curbelo 1783). It is important to note that the proceedings included Ygnacio Penaas one of the persons who accompanied Vizente when he reportedly stole cattle from his grandmother Mariana Curbelo, Vicente Alvarez Travieso's widow (Curbelo 1783). In 1809, Calvillo finally received clear title to his remaining two sitios of land (Ivey 1991:42). 
By 1783, Francisco Flores and his son Vicente were operating Chayopines (Ivey 1991:42). The Flores property extended from about Chayopines crossing downriver about five miles (Figure 4); this was the portion Calvillo lost in 1780. Eventually the de la Pena family sold their rights to half of the original Rancho de San Yldelfonso del Chayopin in 1792 to Francisco Flores, losing control over Chayopines Crossing (Ivey 1991:42).

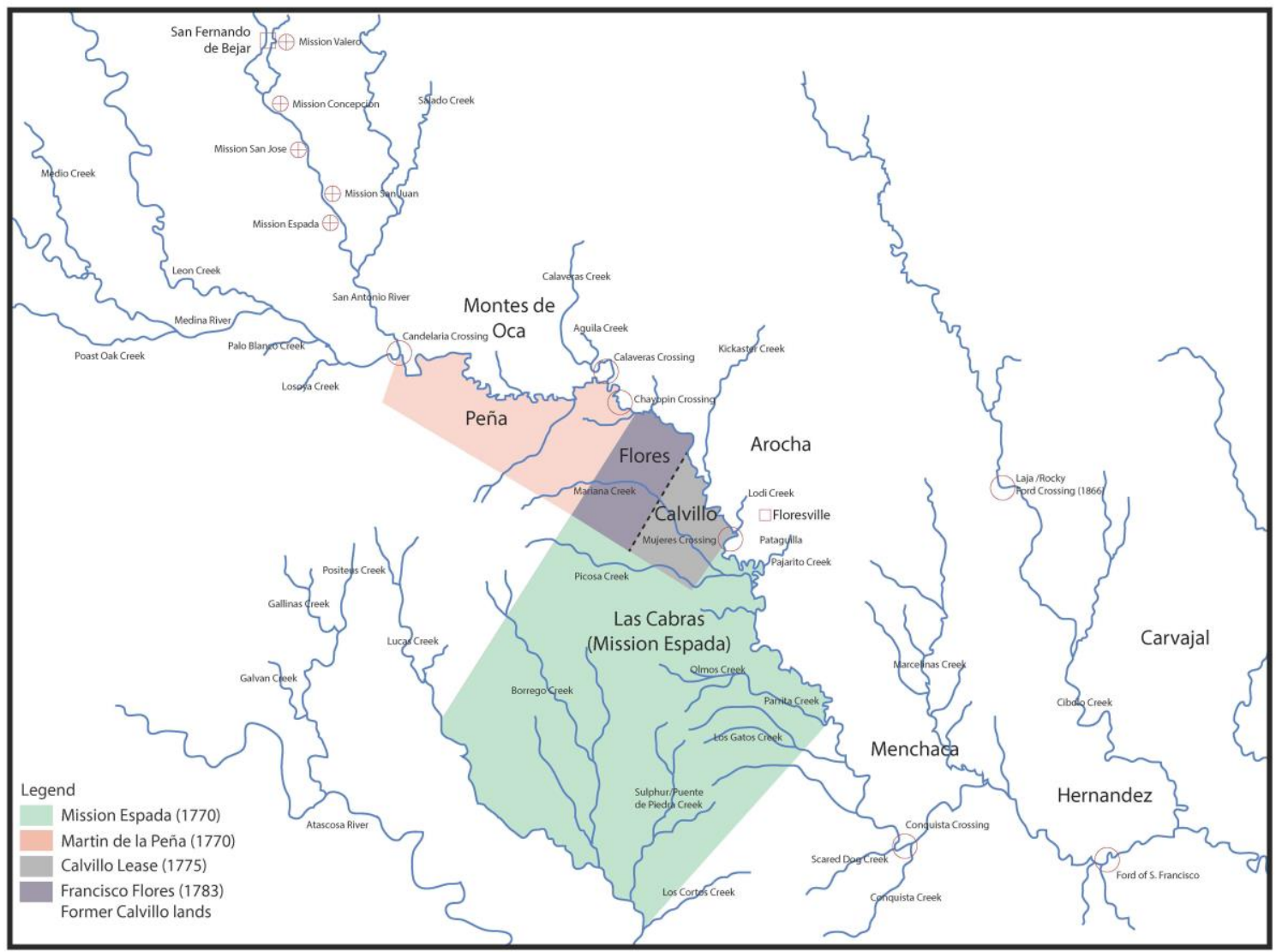

Figure 4. Map showing Flores Ranch in 1783.

\section{THE SOLIS EXPEDITION OF 1767-1768}

Th first accounts of settlement in the area near the location of the Flores Ranch were written by Fray Gaspar Jose de Solis in 1767-1768 during his inspection trip to Texas. Evidence suggests that multiple Chayopines ranchos on either side of the river existed since the area was first settled. In 1791 there were at least two ranches with the Chayopines name: Ygnacio de la Pena's Rancho de San Yldelfonso del Chayopin and Dona Manuela Montes' Rancho de Nuestra Senora de Guadalupe del Chayopin (Cabildo's Report 1791), apparently the northernmost section of Simon de Arocha's San Rafael ranch adjacent to Chayopin crossing (Ivey 1991:44). Previous research has shown that Solis passed through the Flores rancho, owned by Pena at the time. In order to clarify this matter, and because there were multiple Chayopines ranches in the vicinity, it is important to look at Solis' accounts of his trip. 
In 1767, Solis traveled from Mexico to Bexar to inspect the Texan missions. He crossed the Rio Grande close to present-day Laredo, Texas, and then traveled north on the Camino Real to La Bahia (present day Goliad); from there he traveled along the San Antonio River north to the San Antonio missions. Afterwards, he traveled back south along the river down to the area near the intersection with Cleto Creek before turning northeast on his way to East Texas. Upon his return from East Texas he visited missions La Bahia and Concepcion, traveled upriver for a second time to Mission San Jose, and made his way to Rancho El Atascoso before returning to Mexico (Figure 5). His travel diary provides a description of the ranches along his route.

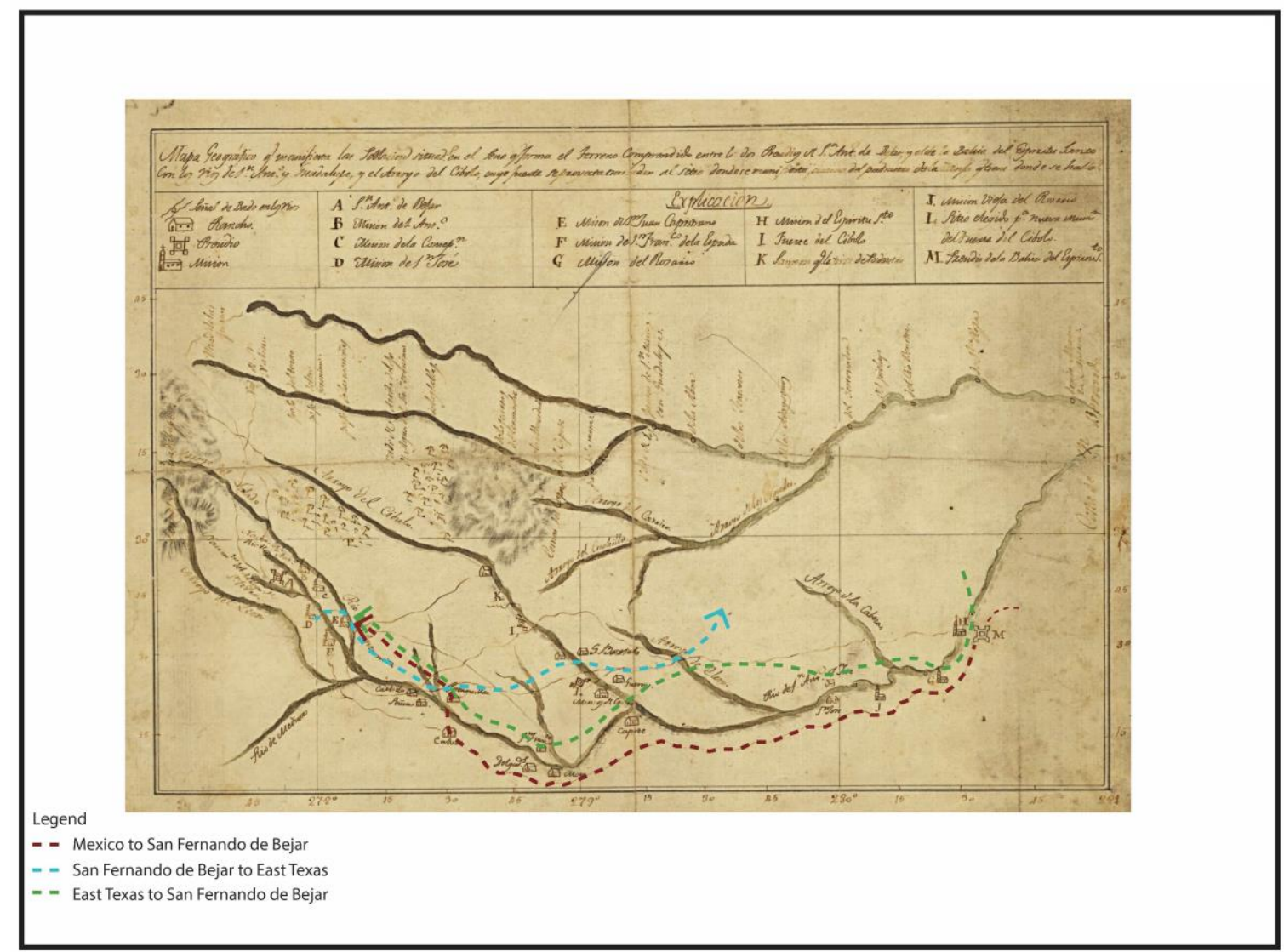

Figure 5. Overlay of the route of the Fray Gaspar Jose de Solis expedition in 1767-1768 on Domingo Cabello's (1780) map of the San Antonio River valley.

According to the translation of the diary by Kress (1932), after leaving La Bahia he "passed through the ranch of the S. S. Joseph, which belongs to the captain of La Bahia...journeyed almost to the River of San Antonio de Vejar going upstream... [and] came to La Escondida" (Kress 1932:47-48). The next day he "passed through La Parrita, through the ranch called El Capote, which is on the bank of the San Antonio River; through the ranch of La Mora belonging to the Mission of San Juan Capistrano on the bank of the same river...came to the Rancho de Labor of Father Cardenas, also on the bank of the river" (Kress 1932:48). It is important to note that all of these landmarks are located on the west bank of the river; until this point it is clear Solis was traveling upriver on the west bank. He then continued: "I passed through the goat ranch on the bank of the same San Antonio River, through La Mota and Arroyo del Padre Mariano...crossed said river [emphasis added] and came to the 
corral of San Juan Capistrano" (Kress 1932:48). According to the landmarks mentioned in his account Solis crossed on to the east bank of the river somewhere near present day Mariana/Picosa Creek, likely through Mujeres Crossing on to Pataguilla, Mission San Juan's Ranch (Ivey 1991:23). The next day he "passed the Salado River at the crossing of the San Antonio River, near the Mission of San Juan Capistrano" (Kress 1932:48). If there was a Chayopines ranch on the west bank of the river it would have been further upriver from where he crossed over to Pataguilla on the east bank of the river.

Fray Gaspar Jose de Solis then visited the San Antonio missions and traveled back the same way on his way to East Texas. He "left the mission of San Joseph... went by the Mission of San Juan Capistrano, crossed the Salado River...and came to the pool of Quinones...that is on the edge of the big woods, or Monte del Diablo" (Kress 1932:53). He remained there for the next day because of bad weather and then he "set out, passing through the Calaveras, and came to the Chayopines crossing of the San Antonio River...said mass and set up the Holy cross" (Kress 1932:53). After leaving Mission San Jose, on the west bank of the river, he implied crossing over to the east bank since he passed by Mission San Juan and Calaveras Creek, both located east of the river. His description puts Chayopines south of Calaveras Creek on the east bank of the river. The Chayopines that Solis stopped at, said mass, and set up a cross at, was close to the Pena ranch but on the east bank of the river. The next day he "passed through La Patanya, through Los Pajaritos, and came to Marcelino creek" (Kress 1932:53), all located east of the river. This corroborates the possibility mentioned above that at this point he was traveling on the east bank of the river. After going by the ranches of San Bartolo, Guerra, and Amoladeras he continued his travel to East Texas.

On his way back to San Antonio from East Texas and after stopping at the missions of La Bahia and Rosario he wrote that he "came to La Escondida...reached the ranch of the Honorable Captain of the Presidio of San Antonio de Bejar, which is called San Francisco...reached the Chayopines, ranch of the honorable Priest of said presidio" (Kress 1932:73). From there, he traveled upriver to Mission San Jose. Solis' account is unclear and not very descriptive, making it difficult to locate exactly where he was along the river. He first noted crossing La Escondida after passing through the ranch of S. S. Joseph on his initial travel from La Bahia to San Antonio; this is likely Escondida Creek, west of the River. He then mentioned stopping at San Francisco, which belonged to Captain Jose Antonio Menchaca and was located on the east bank between the river and Marcelinas Creek (Jackson 1986:93). Solis did not mention crossing the river, so it is possible that he left La Bahia, traveled on the east bank, passed by the mouth of Escondida Creek at the river, continued on to San Francisco, and then upriver to Chayopines.

According to Solis, he stopped at the Chayopines ranch of the "honorable Priest of the said presidio" (Kress 1932:73). It is possible, although highly unlikely, that this priest was Jose Antonio Yldelfonso de la Pena, Martin de la Pena's son, who was priest at the parochial church of Nuestra Senora de la Candelaria in San Fernando (Ivey 1991:41). Solis did not mention which route he took from Chayopines to Mission San Jose. On his previous visit he had followed the east bank of the river up to Calaveras Creek, went by Mission San Juan, and then crossed the river to get to Mission San Jose. It is likely that he would have followed his previous route. If he was at San Francisco on the east 
bank of the river he would have had to cross over to the west bank to get to Pena's ranch, then go back to the east bank to follow his previous route to Mission San Jose.

It is also known that Simon de Arocha settled Rancho de San Rafael by 1766 on the east bank of the river and that he was head of the Bexar militia. Thus it is possible that Solis was referring to the Arocha's settlement ( Jackson 1986:91). According to a letter from Santiago de Zuniga written in 1788 regarding "an order of payment issued against Don Simon de Arocha, when [Zuniga] called upon him to make payment, he offered to do so with cattle from his Rancho de los Chayopines" (Santiago de Zuniga 1788). The Chayopines rancho owned by Simon de Arocha in 1788 does not appear on a 1791 report of ranches along the San Antonio River (Appendix A). It is unknown at this time if his Rancho Chayopines changed name and became San Rafael, or if he originally had two ranches. The 1791 report does list the Rancho de Nuestra Senora de Guadalupe del Chayopin owned by Manuela Montes de Oca (Cabildo's Report 1791), Juan de Dios Arocha Curbelo's widow. Juan de Arocha was Simon's brother, suggesting that the Chayopines rancho referred to in Zuniga's letter later became Juan's rancho. It is likely that the Chayopines ranch visited by Solis was Manuela Montes' and not Martin de la Pena's, as previous research had shown. My research indicates that it is highly possible Solis did not visit the Flores property during his trip.

\section{FLORES RANCH}

As mentioned previously, the Pena family was occupying their land up until at least 1791 (Cabildo's Report 1791), and Francisco Flores and his son Vicente were operating Chayopines by 1783 (Ivey 1991:42). It appears that Francisco Flores acquired two sitios of land that Ignacio Calvillo lost due to failing to pay rent to Mission Espada in 1780 (Ivey 1991:42). It is likely that the Francisco that acquired Calvillo's property and inhabited Chayopines in 1783 was Francisco Javier Flores de Abrego, Juan Jose Flores de Abrego's brother, and not his grandson Francisco Antonio, who received title to the Flores Ranch in 1834.

According to land grant \#694 at the Bexar Archives, Ignacio Villaseñor and Concepcion Flores requested title of one sitio of land for ganado mayor in 1809 (Villaseñor 1809). Concepcion Flores was Francisco Antonio's sister and Ignacio Villaseñor was their brother in law, married to Maria Gertrudis Flores. Th document reads as follows:

nuestro padre Don Pedro Flores ya difunto conpro al defunto Don Ygnacio Pena, un Citio de tiera de ganado mayor. Mi padre no obtuvo titulo de propiedad, ni el que le vendio lo tubo y de ese modo estamos manteniendo nuestros vienes en aquel citio en terreno nomvrado los chayopines (Villaseñor 1809).

Our father Don Pedro Flores, deceased, bought from Don Ygnacio Pena, deceased, ...my father did not get a property title, neither he who sold to him had it and in that way we are maintaining our property in that location at the site known as Chayopines.

It is unknown why if Francisco Javier Flores and his son Vicente inhabited the property in the 1780s, his niece Concepcion claimed the land was inhabited by his father Pedro. However, it is 
possible that as noted previously although Pedro's brothers Juan Jose and Joaquin were at Chayopines in the 1780s, Pedro might have taken over the rancho at some point.

Jose Flores responded to Ignacio Villaseñor and Concepcion Flores' request after visiting the property as follows:

[el terreno] se haya citado en las marjenes del Rio San Antonio y Medina, en los agostaderos nombrados San Yldelfonso de los Challopines...se haya el suplicante radicado con jacal y corrales, a la parte de abajo ynmediato a las fabricas del interesado se ha establecido Don Francisco Farias...con un chamacuero y corral y labor...[en el] llano que esta enfrente de la fabrica del interesado; en dicho llano se halla una senal o mojonera de piedra la qual se ignora quien la puede haver puesto, respecto a que el padre Frai Pedro Norema dice se hayan los documentos de las Miciones en el archivo de Gobierno y algunos de los interesados dicen haverlas puesto sin medida de Juez los padres de las Miciones (Villaseñor 1809).

[the site] is located at the bank of the San Antonio and Medina Rivers, at the pastures named San Yldelfonso de los Chayopines...the applicant is found residing with jacal and corrals, on the lower part immediate to the applicant's building Don Francisco Farias has established...with a chamacuero and corral and labor...[at the] plain that is in front of the applicant's building; in said plain there is a stone signal or mojonera and is unknown who placed it there, in respect to Father Pedro Norena saying that the documents of the Missions are at the Government archives and some of the interested parties say the Missions put them without any measurement of a Judge.

The Chayopines rancho that Concepcion and Ignacio were claiming was located immediately south of Francisco Farias' settlement (Figure 6). Francisco Farias was Maria Micaela de la Pena's son, and Micaela was Ignacio de la Pena's sister. A list of sindicos in the area published in 1810 shows two ranches in the Chayopines area: the Ranch of San Ildelfonso de los Chayopines occupied by Jose Francisco Farias and his wife Maria Encarnacion Rosales, and the Ranch of los Dolores y Chayopin occupied by Ignacio Villaseñor and Maria Gertrudis Flores (Appendix B). It is likely that at least by 1810, the original San Ildelfonso de los Chayopines was still owned by the Pena family (or at least part of it), and the sitio that Concepcion Flores and Ignacio Villaseñor requested in 1809 was the area between Chayopines and Las Cabras that Ignacio Calvillo had lost. However, if this was the case, Pena would have to have acquired the land Calvillo lost and then sold that to Flores. It is unknown why Concepcion requested title to only one sitio in 1809 if according to Ivey (1991:42), by 1792 the Flores family was occupying half of the original San Yldelfonso de los Chayopines land which would have amounted to more than one sitio of land.

It is also unknown if Concepcion Flores' claim was found valid in 1809 since title to the Flores property was not issued until 1834. It is possible that since a mojonera was found at the site and the records of the mission lands were not available for reference, the claim remained unprocessed. It is also possible that the mojonera found in 1809 marked one of the original boundaries of former Mission Espada lands, which would substantiate the fact that Flores was granted part of Ignacio Calvillo land 
that had belonged to the mission. Regardless, this document provides clear evidence that Pedro Flores, Francisco Antonio's father, purchased land from Pena prior to 1809.

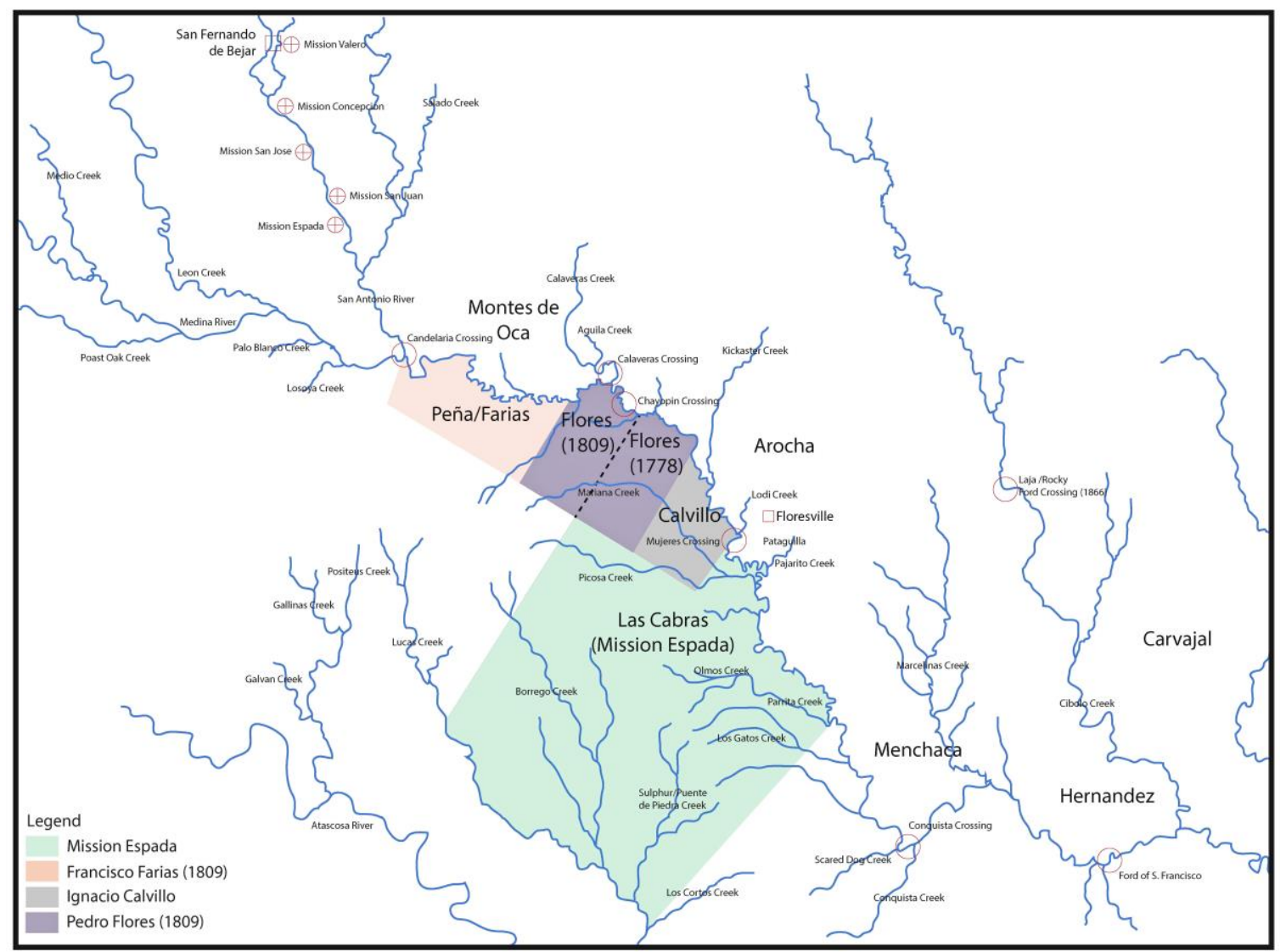

Figure 6. Map of Flores Ranch in 1809.

According to the property's 1834 survey, Francisco Antonio Flores initially requested title to four sitios of land in 1827 (Figure 7). His request reads as follows:

hago presente que tanto mi difunto padre como yo despues de su muerte hemos ocupado y poceido de buena fee con nuestros vienes de campo y labores el terreno sobre la banda occidental del Rio de Bexar en el paraje Nombrado los Chayopines y que hayandome en el dia con numerosa familia y algunos vienes de ganado mayor que me vinieron por erencia del sitado mi difunto padre y que con mi industria e procurado conservar y aumentar en los tiempos mas aciagos de la Guerra y revoluciones padecidas en esta frontera...suplico a V.S. que havida consideración al merito y derecho que por todo lo espuesto tengo adquirido sobre el referido terreno se sirva mandar se me marsenen en el cuatro citios de tierra para labor y agostadero...otorgándome de ellos el correspondiente titulo (Flores 1834).

I make present that my deceased father, as well as myself after his death, have occupied and possessed in good faith, with our field goods and labor, the site on the west bank of the Rio de Bexar at the paraje named los Chayopines, and that finding myself this day with numerous family and some ganado mayor that came to my by inheritance from the said my 
deceased father, and that with my industry I've procured to conserve and augment in the hardest times of War and revolutions endured in this frontier...I ask His Lordship, that taking into consideration the merit and right that I have acquired over the said site due to all the previously exposed, to order the four sitios of land for labor and pasture furrowed... giving me the corresponding title over them.

According to his request he and his family had inhabited the land prior to 1827 with cattle and other goods he inherited from his father. He also claimed that his father settled the land before him, thus implying an even earlier date for the occupation of the ranch by the Flores family. Flores' request was approved by the Governor in 1828 (Flores 1834).

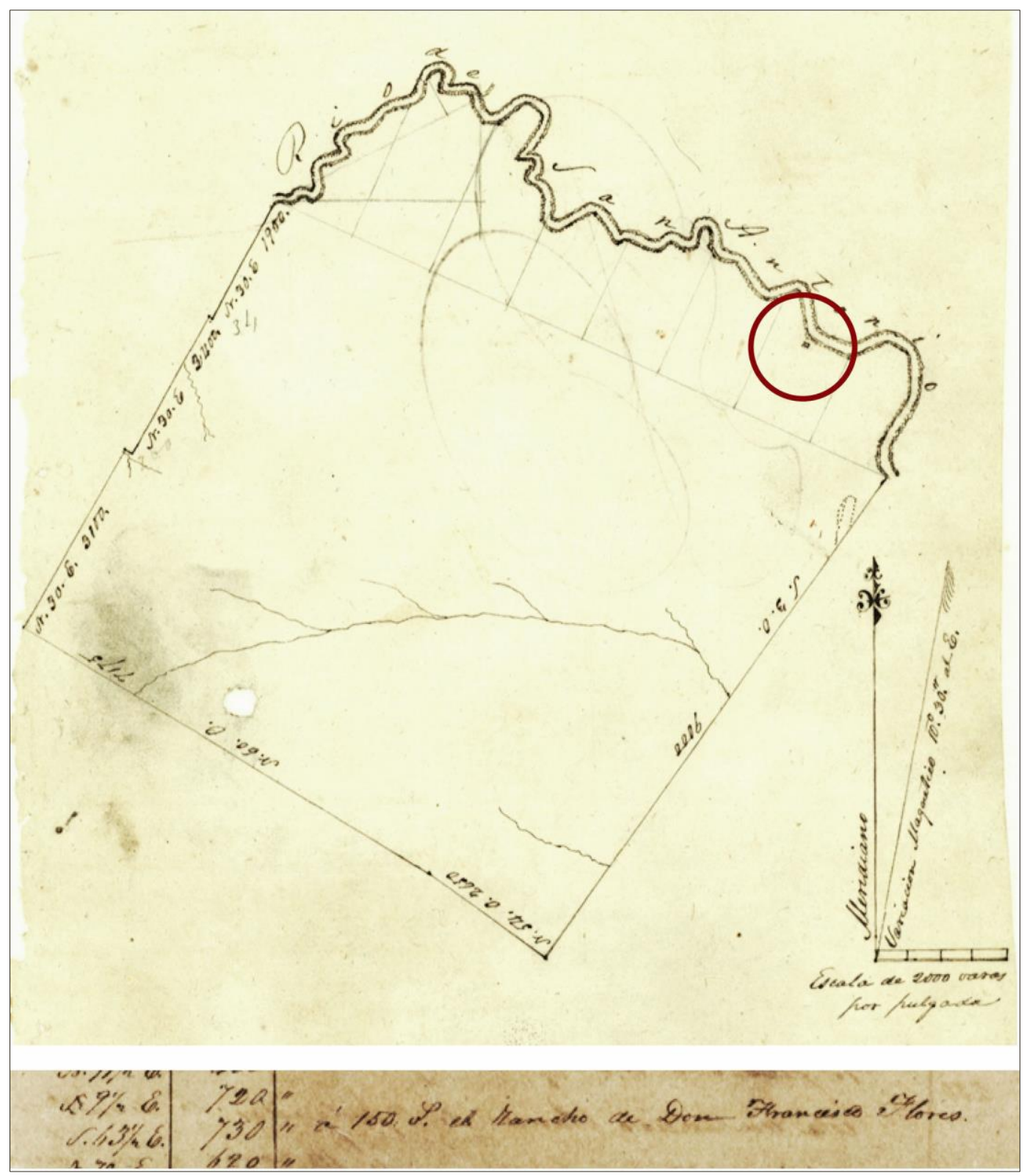

Figure 7. Survey of four sitios granted to Francisco Flores in 1828 showing location of the ranch as indicated in the survey notes ("Flores" 1834). 
In 1833, Flores requested an additional two sitios and two labores adjacent to the four he previously received on the west bank of the San Antonio River, or wherever there was vacant land available (Flores 1834). In his request he stated he was over 50 years old, that the land he had at that time was not large enough to contain sufficient cattle for him to comply with the Law of Colonization no. 190, that he met the requirements of the article 12 of Law no. 128 of 1830 and that he was making his request according to a certification issued by the City of San Fernando de Bejar which included a list of all public positions he served on (Flores 1834). A response to his request was issued a few months later stating that no land was vacant on the river banks and that at that time it was not possible to verify if any land was vacant to the west of his property since there were too many claims over the same area. The response also stated that if the land has not been awarded to anybody else, he should have priority over such land.

In 1834, the Governor awarded him one sitio and one labor of land (per the Law no. 128 of 1830) in the area he initially requested as long as title had not been previously issued to anyone else (Figure 8). The land, including five sitios and one labor, was surveyed by Byrd Lockheart in 1834. The

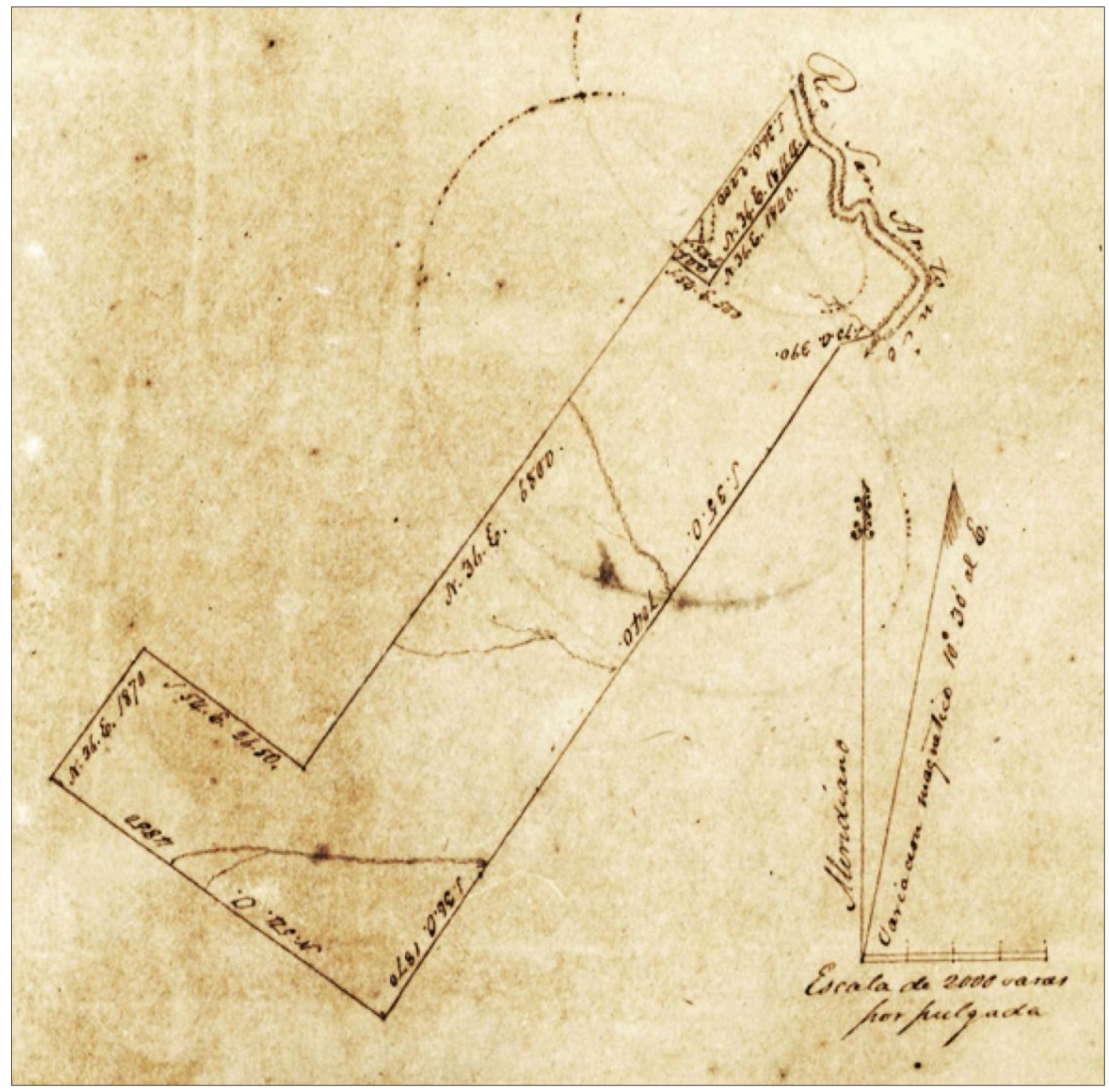

Figure 8. Survey of one sitio and one labor granted to Francisco Flores in 1834 (Flores 1834). 


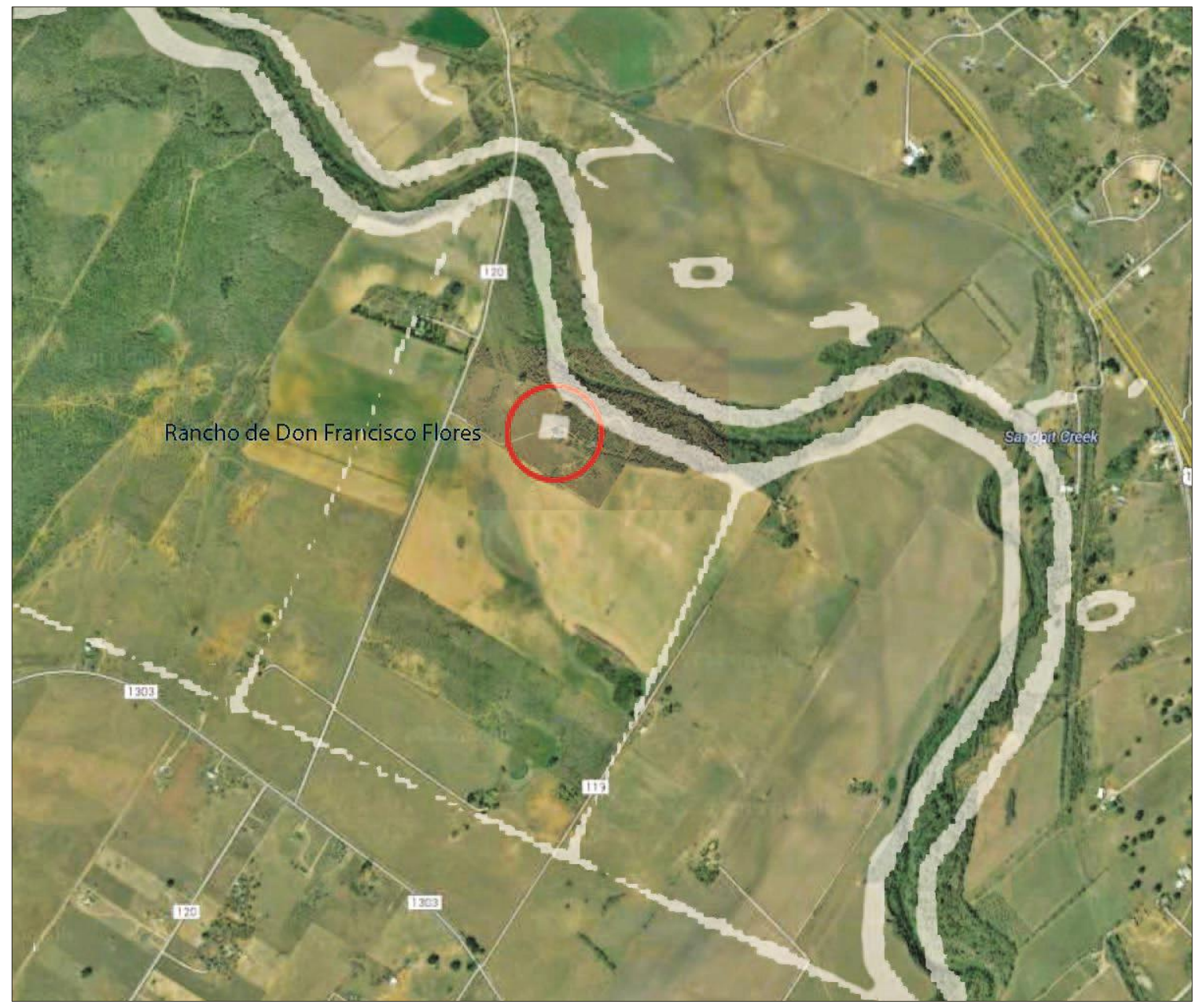

Figure 9. Overlay of original survey showing the location of the existing structures on site (Flores 1834).

1834 survey clearly showed that a structure existed on the property. It is likely that at the time the property was surveyed, the original adobe rooms of the main house (still extant) were present and according to page 14 of the deed, the "Rancho de Don Francisco Flores" was identified both in the survey notes and the metes and bounds (Flores 1834). The location of the Rancho on the survey corresponds to the location of the structure today, clearly supporting the premise that the building was present by 1834 (Figure 9). Francisco Flores claimed to be over 50 years old in 1833 and according to Ivey, Francisco Flores and his son Vicente were operating Chayopines by 1783 (Ivey 1991:44); it is likely that the original adobe structure at the Ranch was built prior to at least the 1780s.

According to a 1932 interview of Bruno Villareal, who was 88 years old at the time, "the old Flores house...had only three rooms when he was a boy of eight [in 1852]...the roof was thick with adobe... at each of the four corners of the house there was a little fort. The corners were just big enough for one man and had loopholes...when Indians were on the warpath, people from miles around came to the Flores house for protection" (Hagner 1940). It appears that a stone church was located across from the house, and a cemetery with at least three to eight graves and a monument with a partially legible description (Figure 10) were found in the church yard (Harlohs 1968:2). 




Figure 10. Headstone marker found on site (Harlohs 1968). 


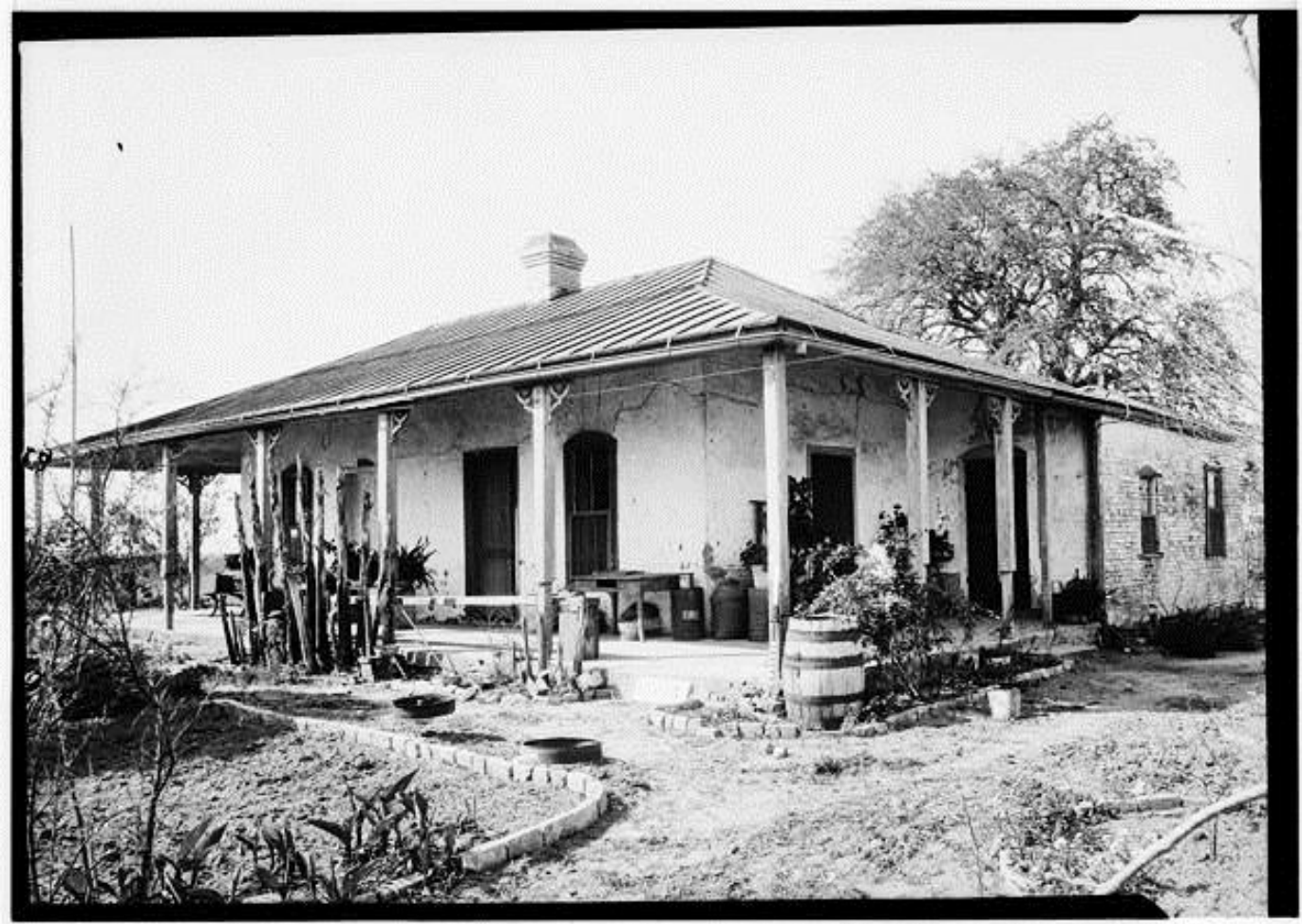

Figure 11. Southeast elevation (South front and East side), Francisco Flores Ranch House, Floresville, Wilson County, Texas. Source: HABS/HAER/HALS Collection from the Library of Congress, photo by Arthur W. Stewart.

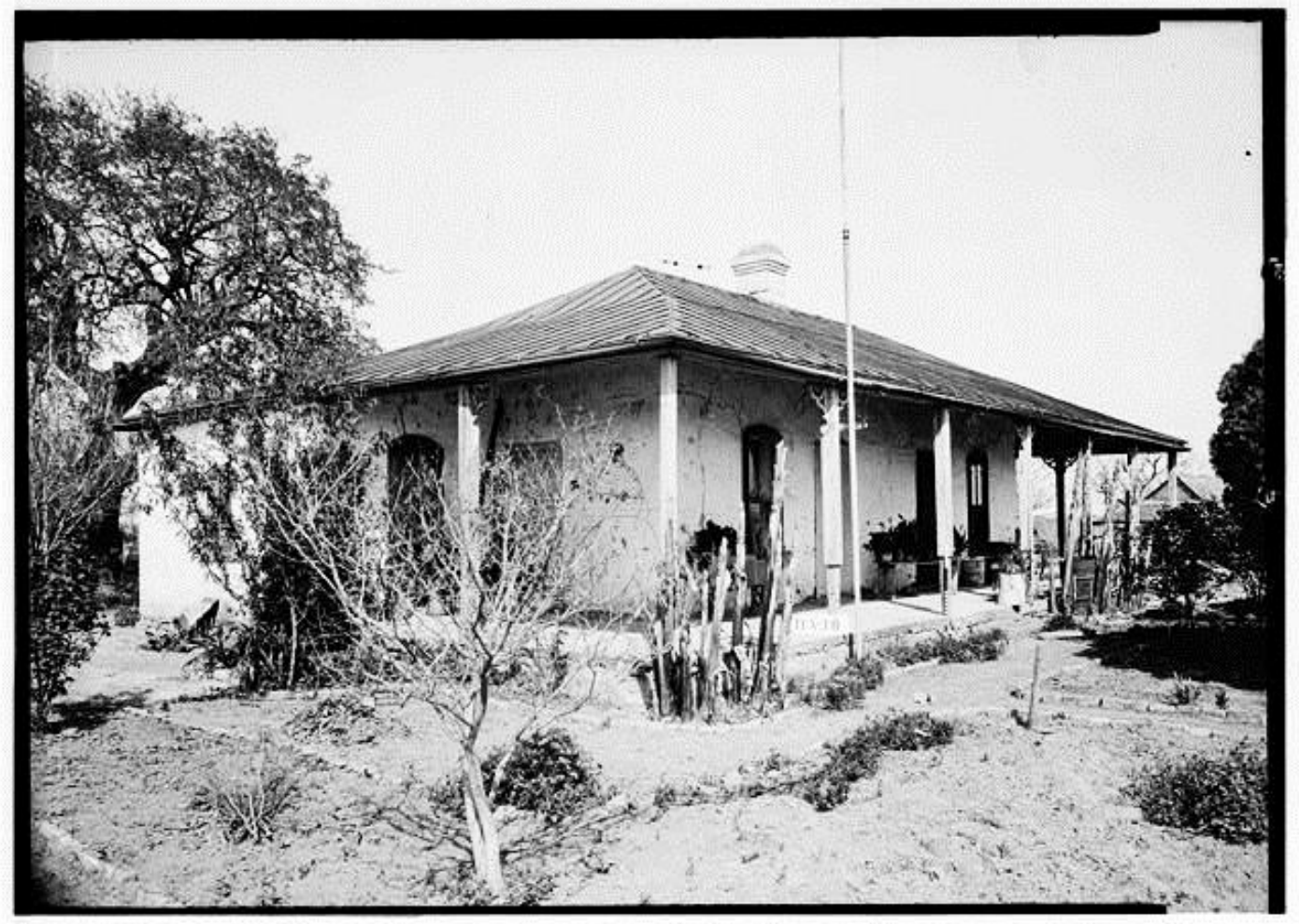

Figure 12. Southwest elevation (South front and West side), Francisco Flores Ranch House, Floresville, Wilson County, Texas. Source: HABS/HAER/HALS Collection from the Library of Congress, photo by Arthur W. Stewart. 


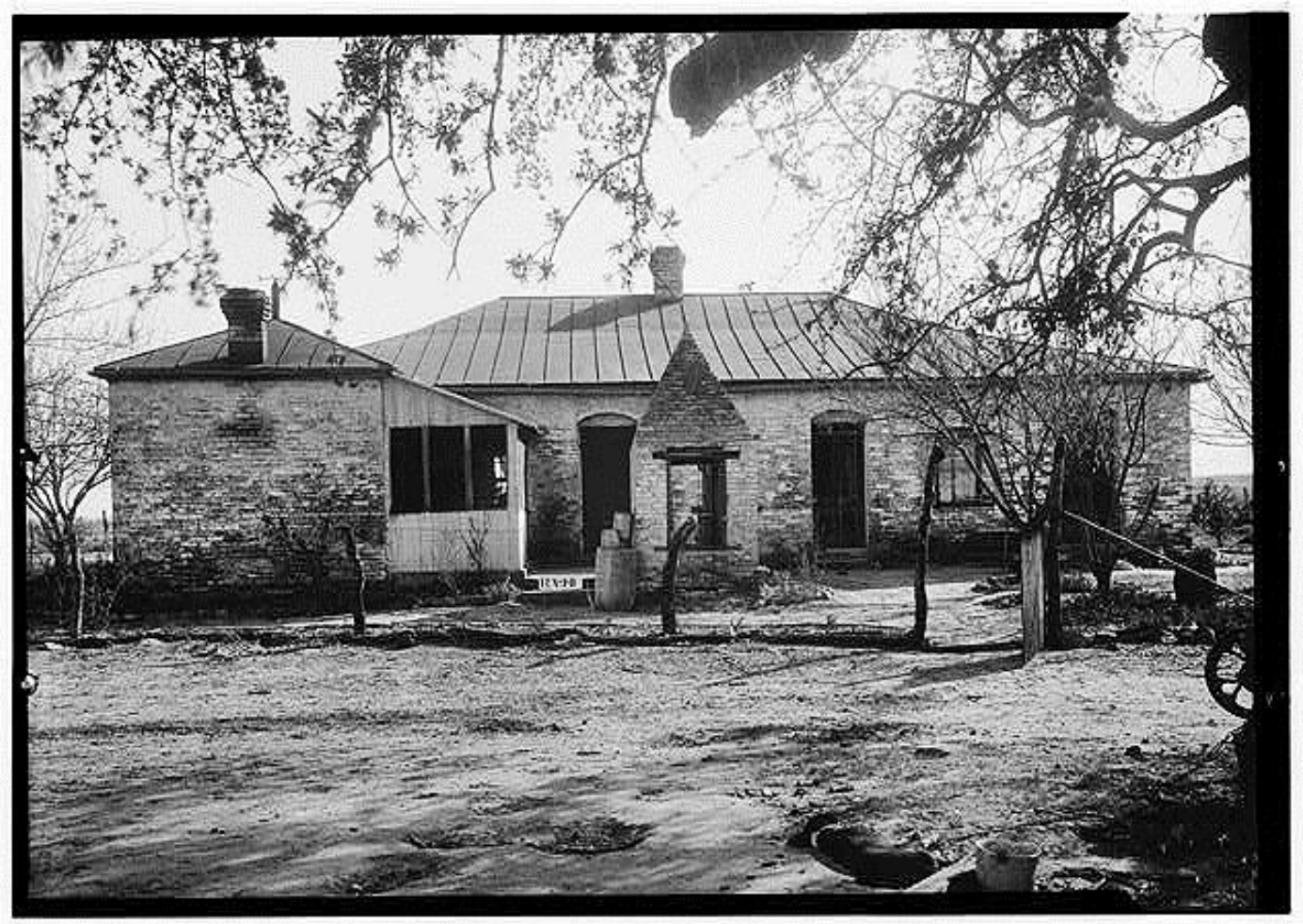

Figure 13. North elevation (rear), Francisco Flores Ranch House, Floresville, Wilson County, Texas. Source: HABS/HAER/HALS Collection from the Library of Congress, photo by Arthur W. Stewart.

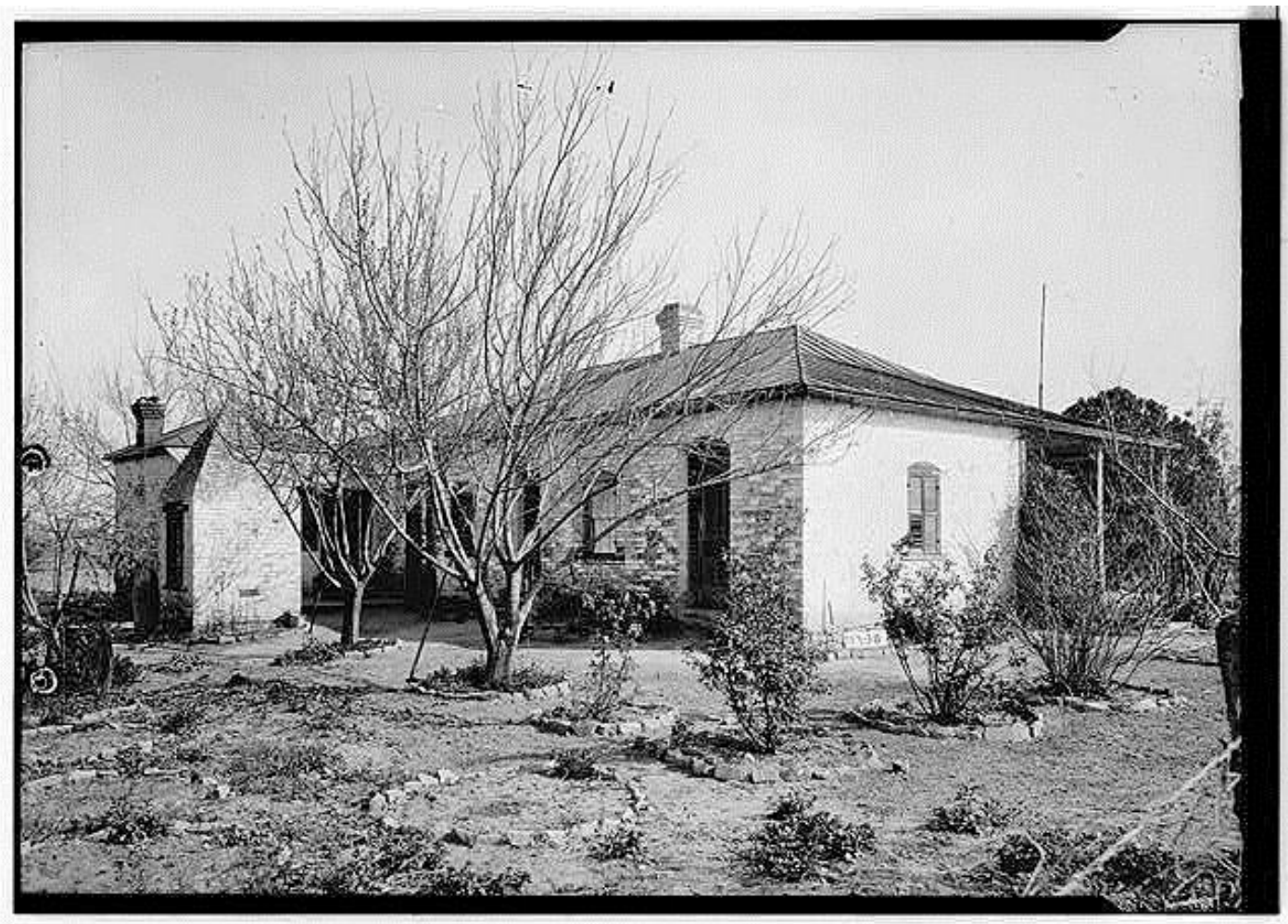

Figure 14. Northwest elevation (West side and North rear), Francisco Flores Ranch House, Floresville, Wilson County, Texas. Source: HABS/HAER/HALS Collection from the Library of Congress, photo by Arthur W. Stewart. 
The present-day ranch complex includes a small adobe house with multiple additions in wood and brick. Th main house was documented and recorded in the Historic American Building Survey (HABS) in 1936 (Figure 11-14). Evidence visible from the interior of the structure shows the original flat roof was extended to form a gable roof at some point after its original construction. The exterior walls of the house have remains of the plaster cladding, which has a red tint and scoring to give a stone block appearance to the walls. The house has wooden doors and windows. In front of the house there is a brick oven with a pyramidal corbel that forms the top. Across from the main house, there are the remains of a large tree and evidence of a stone wall is visible.

\section{CONCLUSIONS}

Investigation of primary and secondary sources, including original Spanish documents, demonstrates that it is likely that the Francisco Flores rancho was acquired in part from lands that belonged to Ygnacio Pena and Mission Espada/Ignacio Calvillo. The archival information also demonstrates that at least four "Chayopines" ranchos existed in the area. The information I have collected shows that although Father Solis did stop at one of the Chayopines ranchos during his expedition in 1767-1768, it is likely he visited one of the other Chayopines ranchos and not the Francisco Flores property. Further investigation of additional available archival records in the Bexar Archives and others may clarify some of the questions about these ranchos. In addition, further investigation of the history of the surrounding ranches may clarify the boundaries and timeline for the use of these properties.

\section{REFERENCES CITED}

Cabello, D.

1780 Mapa geografi que manifi sta las poblaciones situadas en el seno que forma el terreno comprendido entre los dos presidios de San Antonio de Bejar y el de la Bahia del Espiritu Santo con los rios de San Antonio $y$ Guadalupe, $y$ el Arroyo del Cibolo. Map No. Q47, Records of the Bureau of the Chief of Engineers, National Archives at College Park, Maryland.

Cabildo

1791 Cabildo's report on number of ranches in Bexar as requested by Salcedo on Oct. 3, 1791.

Official Report. Bexar Archives Online, Briscoe Center for American History, The University of Texas at Austin, http://www.cah.utexas.edu/projects/bexar/gallery_doc. php?doc=e_bx_006459, accessed June 4, 2014.

Cargill D. A., M. Brown, L. C. Nordt, and C. B. Bousman

1998 Archaeological Survey at Rancho de las Cabras, San Antonio Missions National Historical Park, 41WN30, Wilson County, Texas. Archaeological Survey Report No. 286. Center for Archaeological Research, The University of Texas at San Antonio. 
Curbelo, M.

1783 Mariana Curbelo vs. Francisco Vicente Flores, demanding stock taken from the plaintiff's ranch. Proceedings. March 8, 1783. Bexar Archives Online, Briscoe Center for American History, The University of Texas at Austin, http://www.cah.utexas.edu/db/dmr/image lg.php?variable=e_bx_008266_045, accessed June 19, 2014.

Flores, F.

1834 Flores, Francisco. March 23, 1834. Patent 99, Vol. 31, Patents, Archives and Records Program, Texas General Land Offi e, Austin.

Hagner, L. M.

1940 Alluring San Antonio, Through the Eyes of an Artist. The Naylor Company, San Antonio.

Harlohs, K.

1968 Rancho Floreno. Floresville Chronicle Journal, June 27, 1968.

Hazlewood, C.

2010 "Floresville, TX.," Handbook of Texas Online. June 12, 2010. http://www.tshaonline.org/ handbook/online/articles/hgf03, accessed April 14, 2014.

Ivey, J.

1991 Mission Land Use in the San Antonio River Valley. Unpublished MS on file with the author.

Jackson, J.

1986 Los Mestenos: Spanish Ranching in Texas, 1721-1821. Texas A\&M University Press, College Station.

Kress, M. K. (translator)

1932 Diary of a Visit of Inspection of the Texas Missions Made by Fray Gaspar Jose de Solis in the Year 1767-1768. Southwestern Historical Quarterly 35:28-75.

Oca, J. J. Montes de

1778 Oca, Juan Jose Montes de. Unfinished Titles, Archives and Records Program, Texas General Land Office, Austin.

Pena, M. de

1770 Pena, Martin de la. Unfinished Titles. Unfinished Titles, Archives and Records Program, Texas General Land Office, Austin. 
Santiago de Zuniga

1788 Santiago de Zuniga vs. Simon de Arocha for payment of debt. Legal Instrument. 14 May 1788. Bexar Archives Online, Briscoe Center for American History, The University of Texas at Austin, http://www.cah.utexas.edu/projects/bexar/gallery_doc.php?doc=e _ bx_005131\&t=53\&s=40, accessed June 4, 2014.

Villaseñor, I.

1809 Villaseñor, Ignacio and Concepcion Flores. Unfinished Titles. Bexar Archives, Land Grants and Sells, No. 694. Bexar County, Texas. 


\section{APPENDIX A}

\section{TRANSLATION OF “CABILDO'S REPORT ON NUMBER \\ OF RANCHOS IN BEXAR AS REQUESTED \\ BY SALCEDO ON OCT. 3, 1791" \\ (CABILDO'S REPORT 1791)}

Señor Governor of this Province of Texas, Lieutenant Colonel Don Manuel Munoz.

The cabildo, justice and regiment of this villa of San Fernando, imposed by the officio of the $6^{\text {th }}$ of the current [month] in the superior disposition that is communicated by Senor commandant general dated October $3^{\text {rd }}$ last, so that it is given prompt notice to all cities, villas, places, haciendas and ranchos within this province, we state that the ranches inhabited by people and cattle are the following:

Don Simon de Arocha owner of the Ranch of San Rafael de la Pataguiya Don Luis Antonio Menchaca owner of San Francisco de los Tarais

The following are without people but with property:

Don Tomas Travieso owner of the Ranch of San Vicente de las Mulas

Don Jose Placido Hernandez owner of San Bartolo del Cerrito

Doña Leonor Delgado owner of San Jose de los Alamos

Don Salvador Rodriguez owner of Nuestra Señora de la Candelaria

Don Ygnacio Calvillo owner of Nuestra Señora de Guadalupe de las Mujeres

Don Ygnacio Peña owner of San Ildefonso del Chayopin

Doña Manuela Montes owner of Nuestra Senora de Guadalupe del Chayopin

Don Macario Zambrano owner of Nuestra Senora de Candelaria de las Calaveras

Don Diego Irineo Enriquez owner of Santa Cruz de la Laja

The ones without people or property are the following:

Doña Antonia de Armas owner of San Lorenzo de las Mulas

Don Manuel Delgado owner of San Cristobal de Espanta Perros

Doña Josefa Quinones owner of San Miguel de las Amoladeras

This is what we know and can inform to you on this particular, which we forward to your hands for your intelligence.

God keep you many years. Bexar, November 8, 1791. 
Francisco Arocha

Pedro Flores

Marcos de Zepeda

Angel Navarro

Salvador Rodriguez

Juan Joseph de la Santa

Clemente Delgado

Francisco Bueno

Vicente Amador 


\section{APPENDIX B}

\section{TRANSCRIPTION OF "SINDICO REPORTS OF THE BEXAR JURISDICTION, TAKEN IN THE YEAR 1810" (JACKSON 1986:630-631)}

Jurisidction of Sindico Ignacio de Arocha:

- San Rafael de Pataguia: Ignacio de Arocha (son of Simon); wife, Maria Josefa Salinas (age 34, Bexar); children Jose Felix (14), Maria Gertrudis (12), Jose Antonio (10), 2 servants and families.

- Nuestra Senora de Guadalupe y Paso del Chayopin: Dona Manuela Montes (55, widow of Juan de Arocha); children Manuel (33), Jose Maria (30); 3 servants and families.

- Los Dolores y Chayopin: Ignacio Villaseñor (45, Saltillo); wife, Maria Gertrudis Flores (36, Bexar); daughter Maria Josefa (13); 3 servants.

- San Ildelfonso de los Chayopines; Francisco Farias (45, Bexar); wife, Encarnacion Rosales (43, Bexar); children Jose Antonio (20), Domingo (11, adopted); niece Antonia Rodriguez (4); 2 servants (In 1791 this ranch was owned by Ignacio Pena).

- La Santa Cruz y Paso de las Mujeres: Ignacio Calvillo (77, Aguascalientes); and wife, Antonia de Arocha (65, Bexar, sister of Simon de Arocha); grandchildren Ignacio Casanova (22); Francisco Casanova (10); 3 servants. Also agregados (tenants) Gavino Delgado (55) and wife, Maria Calvillo (45, Ignacio's daughter); Jose Saucedo (46); wife, Juana Calvillo (35); 3 children; 4 servants.

- San Juan Nepomuceno y Pataguias: Jose Clemente de Arocha, curate (45); 11 servants (see no. 1 above).

- Pataguia: Tomas de Arocha; 2 servants and families (see no. 1 above).

- La Soledad, in Pataguia: Francisco de Arocha; 2 servants. (Nos. 6-8 were divisios of Simon and Juan de Arocha's 8-league grant, along with no. 2. Juan died in 1788; Simon, in 1796).

- San Antonio del Sabinito: Manuel Nunez, who lived in Bexar; 3 servants.

- Santa Gertrudis, in Las Cabras Viejas: Manuel Barrera (son of the diezmero Juan), who lived in Bexar; ranch kept by 3 servants and families.

- La Laguna de las Animas (Lagoon of the Souls): Juan Manuel Sambrano (38, subdeacon, son of Jose Macario); 32 servants and 2 slaves. 